\title{
Contextualisation of Academic Terminology Collocations
}

\author{
Instructor Ya'arub Mahmood Hamiedi, M.A. \\ University of Diyala / College of Education for Human \\ Sciences/ Department of English \\ Yarob378@gmail.com
}

\section{Abstract:}

This paper investigates the significant role of ' context' in the clarification and explication of words in English. It also sheds light on the linguistic environment within which the word operates, i- e- the collocates that occur in concomitance with this word .The research aims at exploring the formulation of words and vocables within the due context. This exploration, however, is conducted through the use of academic terminology in the framework of well-maintained context under certain semantic restrictions. Moreover, this work is an attempt to come up with answers to such questions as : What is meant by 'context'? How important is 'contextualization' for the clarification of words ? Do 'context' and 'collocationality' both contribute to the full understanding of words ?

The objective of the study is to investigate, explore and probe into the unraveling role of 'context' and 'contextualisation'. The study is a two-fold investigation aimed at getting acquainted with on- campus terms as well as the framework within which such terms operate and perform their communicative function. The study concludes that "context" is inevitable for the conscious awareness desperately required by learners of English to fully grasp the sense intended. This, above all, saves the learner both the effort and time that may be consumed in the quest for the meaning of a word out of context.

Key Words: Contextualised Academic Terms, Academic Terminology, Academic Terms in Context. 


\section{سياق متلازمات المصطلحات الأكاديمية \\ م. يعرب محمود حميدي \\ جامعة دياله / كلية التربية للعلوم الإنسانية}

\section{قسم الاغة الانكليزية}

\section{الملخص:}

يرمي البحث الى تتاول الدور الهام للسياق والذي يسهم في إيضاح وتبيان الدفردات في اللغة الإنكليزية؛ كما وتسلط هذه الدراسة الضوء على البيئة اللغوية التي تعمل في إطارها المفردة، أي بمعنى آخر تللك المتلازمات التي تصاحب تلك المفردة. وترمي الدراسة الى استشراف الاطراف التركيبية للمفردات في نطاق القرينة التي ترد فيها المفردة ، حيث تم تتاول ذلك من خلال استخدام المصطلحات الاكاديمية ضمن أطر السياقات المحددة بدقة وضمن قيود دلالية معينة ـ وتعتبر هذه الدراسة بمثابة محاولة تهدف الى طرح إجابات على نساؤلات كهذه ، ما المراد بكلمة سياق (قرينة) ؟ وما أهمية وضع المفردة في إطار سياق معين لإيضاح المفردات ؟ وهل أن كلاً من السياق والمصاحبات اللغوية تسهم في استيعاب معنى المفردات؟ تهدف هذه الدراسة الى استكثاف وإبراز دور السياق (القرينة) في إحاطة الغموض عن المفردة إذا ما استخدمت بمعزل عن سياقها الصحيح · إن الدراسة ذات شقين فهي تهدف اللى التعريف بالمصطلحات التي يتم تداولها في نطاق الحرم الجامعي الاكاديمي من جهة وكذللك الأطر

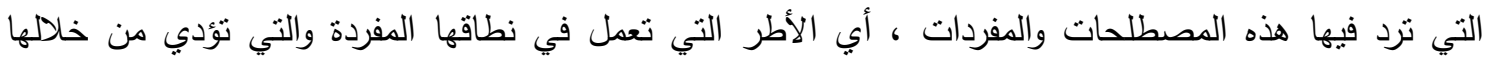
وظيفتها التواصلية .

تخلص الدراسة الى أن(السياق) أو (القرينة) لا مناص أو محيص عنه بغية الفهم الواعي، ذلك الذي يتطلبه

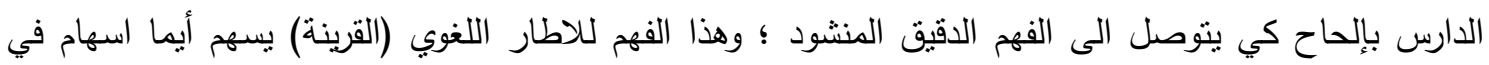
نوفير كلاً من الجهد المبذول في البحث عن معنى المفردة وكذلك الوقت المستغرق في البحث عن معنى تلاك المفردة اذا ما وردت بمعزل عن إطارها اللغوي أي السياق أو القرينة والتي تسهم في إيضاح المعنى المكنى.

الكلمة المفتاح: المصطلحات الاكاديمية في السياق، المصطلحات الاكاديمية، المصطلحات الاكاديمية ضمن القرينة. 


\section{Introduction :}

"Context" can be defined as "those parts of a discourse that surround a word or passage and can throw light on its meaning, "as entered in (Webster's Intermediate Dictionary; 1972; p:157) Furthermore, "context" may be defined in (Webster's New World Dictionary; 1980; p:96) as "the text or speech that comes immediately before and after "a particular phrase or piece of text and helps to explain its meaning." 'To contextualise' is a transitive verb meaning" to place (as a word or activity) in a context," or "to think about or provide information about the situation in which something happens," as elucidated in (Merriam-Webster Dictionary Online). All this placement aims at the interpretation and explication of the word, phrase, or text at issue.

"Contextualisation" is putting language items into a meaningful and real context rather than being treated as isolated items of language for language manipulation practice only. However, contextualising language tries to give real communicative value to the language that learners meet. The context can help learners remember the language and recall it at a later date. Learners can use natural learning strategies to help them understand contextualised language, such as guessing meaning from context.

In the classroom, contextualisation can be as simple as providing an example sentence that uses a new word, or as complex as preparing a telephone role-play to practise functional language.

Context is not the only unravelling factor, yet a collocation of a certain word also contributes to the optimal understanding and naturality of language usage. The collocation of a certain word refers to all the words that co-occur with this word and formulates its natural environment. In this respect. McCarthy (2008: 6) defines it as a pair or group of words that are often used together, and they sound natural to native speakers. He further states that students of English have to make a special effort to learn them because they are often difficult to guess.

The integration of the explication through word-contextualisation with the mastery of word-collocation can thoroughly contribute to the full understanding and typical usage of language. This above all places the foreign learners of English on the right track with regard to the proper usage of language, be it in context or within well-maintained collocability. 
1.1 College : It is "a place of higher education usually for people who have finished twelve years of schooling and where they can obtain more advanced knowledge and get a degree to recognize this," as entered in (Cambridge Dictionary of American English; 2008; p:159). The sense of college as an educational institution requires a certain set of adjectives to co-occur in collocation within a pattern like;

1.1.1 [ Adj + N (= college) ] : This structural pattern may involve certain adjectives with definite meanings semantically congruent with the meaning of 'college'. Of the meanings expressed by such adjectives are:

(i) Specialty : Colleges provide educational services in rigorous specialties. Specialty - indicative adjectives include agricultural, art, FE (= further education), military, music, police, secretarial, teacher training, technical, theological, veterinary, etc. Such collocations are given prominence in contexts such as:

1. He is a graduate from the agricultural college.

2. Talented students are easily admitted into art colleges.

3. There are many cadets at the military college.

4. She has recently graduated from the secretarial college.

5. The teacher training college nearby has undergone many alterations lately.

6. The ministry is constructing a new technical college on the outskirts of the city.

7. 'Jurisprudence' is a major topic of study at the theological college.

8. The veterinary college is located in the suburban area.

(ii) Locality : Colleges, as educational institutions, could be categorized according to the locality within which they are situated. Adjectives or noun modifiers in collocation with 'college' are community, local, etc., as instanced in such contexts as:

9. I think you can enroll in one of the courses at the local college.

10. The community college you are at is a really accredited college.

(Oxford Picture Dictionary; 2008; p:189)

(iii) Feedback : Sixth-form students or else could be an ongoing backfeeder to colleges in general; therefore, back-feeders could be sixth form, tertiary, etc. Such collocations can be contextualised in examples like:

11. You will be admitted into one of the sixth-form colleges if you manage to pass your sixth-form final examinations.

12. Tertiary colleges provide higher education voluntarily nowadays. 
(iv) Tuition : There are certain colleges which admit students for pay. Such colleges can be designated as tutorial, private , university, etc. Such colleges can be detected in concomitance with 'college' in contexts like these:

13. If you can afford it, you can go to a private college.

14. You need a subvention to complete your study at that tutorial college.

1.1.2 [ V $+\mathrm{N}$ (= college) ] : This pattern accounts for another collocation, i.e. [ a verb + college ] - collocation. Verbs that collocate with 'college' are often transitive, with 'college' functioning as direct object. Such verbs may denote :

(i) Enrollment : The sense of 'enrollment' can be signified by verbs such as attend, go to, etc. Such collocations may be highlighted in contexts like:

15. He is now attending college at Edinburgh.

16. After they pass the sixth-form stage, students aspire to go to colleges.

(ii) Completion : The commencement of education, whether at college or in any other educational institution, must come to an end sooner or later. The natural corollary is graduation. This sense requires collocates such as finish, graduate from, etc., which are illustrated through contexts like:

17. Real learning, some experts proclaim, initiates after one finishes college.

18. By the time you graduate from college, you'll have recognized the fact that there are still so many aspects you haven't mastered yet.

1.1.3 [ $\mathrm{N}$ (=college $)+\mathrm{N}$ ] : This pattern of collocation can accommodate nouns as immediate collocates following 'college'. Such nouns can convey certain senses such as:

(i) Faculty : The noun 'college' may, very possibly, be followed by a'faculty' -indicative sense. Nouns suggestive of this sense include lecturer, principal, teacher, staff, etc., as elucidated in such contexts as:

19. He works as a college lecturer at one of the colleges nearby.

20. Your application will be considered by the college principal.

21. College teachers must be knowledgeable and erudite.

22. Here is a photograph of all the college staff.

(ii) Learner : At colleges there are learners that aim at acquiring specialized knowledge in a specific field of study. The learner at college is referred to as student. The following is a context in which this noun is used:

23. College students must abide by the principles and regulations imposed by the Ministry of Higher Education and Scientific Research. 
(iii) Schedule : The college academic year is normally scheduled into parts such as course(s). Notice these contexts:

24. The college course they attended last year was quite intensive.

25. Students are required to enroll in college courses so as to qualify for future requirements.

(iv) Facilities : There are often certain facilities on campus, i.e. there are, for instance, buildings like, chapel, library, laboratory, room, etc., as exemplified within contexts such as :

26. Some students are now holding services at the college chapel.

27. The college library is rich in up-to-date sources and references.

28. Chemistry students are advised to get themselves acquainted with the latest safety measures in college laboratories.

29. We are in desperate need of extension, i.e. of building more college rooms.

1.1.4 [ Prep. At $+\mathrm{N}$ (=college) ] : This collocational pattern serves as a slot for 'at', followed by 'college'. The usage of 'at college' can be well justified in accordance with the fact that this collocation indicates the normal routine existence or work at this educational institution, as stated by Murphy (2004: 248) \& in (Quirk 1983: 148), who further adds that this usage is in British English, while in American English 'in' is normally used. This collocation can be instanced in such contexts as:

30. She is at college in Swindon. (British English)

31. He is in college/ school. etc. (American English)

1.1.5 [ Prep. In $+\mathrm{N}$ (=college) ] : The usage of 'in' as an immediate collocate with 'college' indicates that someone is within the premises of college whether they are affiliates or outsiders, as elucidated by Quirk (1983: 147). This sense is contextualised in :

32. Not all the lecturers are in college at any one time.

2.1 University : The word (noun) 'university' means "an institution giving degrees and more advanced education than is given in schools, and engaging in research," as entered in (An English Reader's Dictionary; 1967; $\mathrm{p}$ : 475). With this meaning, the noun 'university' can operate within a pattern of collocations like :

2.1.1 [ Adj + N (= university) ] : This pattern may be filled in with certain collocates, i.e. with adjectives conveying the sense of :

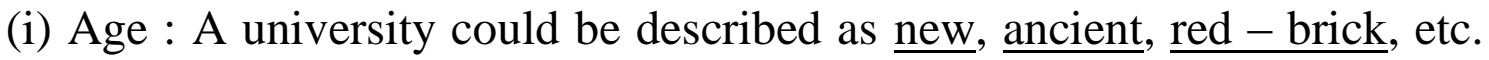
as exemplified in : 
33. Many new universities have been founded recently.

34. Al-Mustansiriyah is one of the ancient universities in Iraq.

35. It is one of the six red-brick universities founded in England that achieved university status before World War 1 .

(ii) Locality : Universities may be categorized according to the locations they are situated in. Thus, with this sense, collocates such as local, provincial, etc. can fill in the adjective-slot modifying 'university' in illustrative contexts like the following :

36. Amanda is now a student at one of the local universities.

37. There is only one provincial university that you may attend.

(iii) Specialty : Another category that can be used to designate universities has to do with the specialty these universities are mainly concerned with. This sense necessitates the use of specialty-indicative nouns or adjectives such as research, teaching, etc. Such collocates can be clarified when contextualised; notice :

38. Research universities must be financially supported by the government.

39. You can give lectures at the provincial teaching university.

It is to be noted that more than one collocate may, very possibly, be in collocation with 'university' or other academic-based vocabularies. In (39) above both 'provincial' and 'teaching' co-occur with university.

2.1.2 [ V $+\mathrm{N}$ (= university) ] : Within the framework of this pattern, some verbs may precede 'university', each at a time. Of these verbs are some that impart the meaning of :

(i) Matriculation : This sense requires verbs like attend, go to, study at, enter, apply for, etc. to collocate with 'university', as in :

40. Those who go to university must comply with the regulations imposed.

41. Miss Kate is now studying at university wishing to be a well-qualified translator.

42. Why do you not apply for university as long as you are keen on study?

43. James entered university while still very young.

44. He attended university, being stimulated by his colleagues.

(ii) Completion : Any study, wherever it is conducted, must come to an end as far as the certificate conferred is concerned. This sense can be expressed by using verbs such as finish(at)_graduate from, leave, etc. The following are illustrative contexts :

45. They finished university last year and then travelled abroad. 
46. After you graduate from university, you must begin life with utmost enthusiasm.

47. Due to straitened financial circumstances, my friend, Brad, left university while still a sophomore.

Notice that the noun 'sophomore' which means 'a second-year student at university', etc. is used in American English as stated in (Webster's Intermediate Dictionary; 1972; p: 730).

2.1.3 [ N (= university) $+\mathrm{N}$ ] : The word 'university' can be followed by certain nouns as collocations and these nouns may give the sense of :

(i) Teaching staff : Nouns indicative of those who are involved in the teaching process include lecturer, professor, teacher, staff, etc. Such collocates can be clarified in the following unravelling contexts :

48. The young man sitting on the bench over there is a university lecturer.

49. This is a photograph of some eminent university professors.

50. University teachers must be highly qualified and very eligible for teaching.

51. The university staff need to be engaged in intensive refresher courses.

(ii) Learners : All learners at university-level can be referred to as student $(\underline{s})$,graduates(s), undergraduate( $(\mathrm{s})$, etc. These potential collocates can be further explicated in contexts such as :

52. I'd rather that university students conform to uniform.

53. University graduates should fill in job vacancies as soon as possible.

54. He proposed that brilliant university undergraduates be rewarded munificently.

(iii) Outcome : Of the results one may come up with in and after the process of study at university are education, degree, course, etc. These, however, are predictable collocates that appear in contexts like :

55. University education should be upgraded all the time through the modern sources available nowadays.

56. It is necessary that everyone should attain a university degree so as to be immune from all the ills and evils of ignorance.

57. Having passed all the university courses with flying colours, she exceptionally took such a pride in her faculties.

(iv) Division : The duration of study at university is often divided into term(s), year, etc., so such collocates can be occasionally seen in collocation with 'university', especially in contexts such as :

58. At the conclusion of the first university term, students usually enjoy a two-week mid-year holiday (vacation). 
59. Most of the lecturers have covered the syllabi of the university year.

(v) Off-study : Students at university usually take some period of time off so as to have some rest and rejuvenate their energy. This allotment of rest contributes to the active resumption of study required for memory jogging. With this off-study sense collocate nouns such as holiday, vacation, etc., as viewed in contexts like :

60. The university (summer) holiday is anxiously awaited by both professors and students so as to enjoy some privacy away from the atmosphere of study.

61. Students in the U.S. usually have a university vacation in mid-June during which most of them travel abroad for sightseeing.

(vi) Enrollment : One needs to be enrolled in any educational institution. This 'enrollment' sense requires collocates such as entrance, entry, place, etc. The following are contexts within which such collocates fit:

62. University entrance is based upon the average that the applicant has.

The collocate 'university entrance' could be in collocation with 'exam', for instance :

63. You should pass the university entrance exam with an average of 60 in order for you to get admission.

64. There is stiff competition for university places.

(vii) Status : Occasionally, a collocate such as chair is used in concomitance with 'university' to form a collocation indicative of stature obtained by an eminent figure at university. Such a collocation can be contextualised in :

65. His aim was to finish his doctorate and obtain a university chair.

(viii) Sections : Within any university there are a number of sections or entities such as department, faculty, etc. ; therefore, such collocates can be detected in contexts such as :

66. All the university departments are supposed to coordinate their efforts to elevate the overall performance for the purpose of the advancement of the university.

67. The president of the university addressed the letter to the entire university faculty.

(ix) On-Campus Facilities : There are some facilities that exist within the university premises including buildings, library, cafeteria, canteen, laboratory, etc. It is, however, possible to add campus, though it is not a facility, but the ground on which facilities stand. These quite predictable collocates can be highlighted in explanatory contexts like : 
68. Within the construction campaign, many university buildings have been erected.

69. You may consult some reliable sources in the university library.

70. There is a long queue at the university cafeteria.

71. The university laboratories must be equipped with the necessary safety equipment.

72. You can buy some writing implements at the university canteen.

(x) Management : Universities are in desperate need of management without which they fall into chaos. Nouns in collocation with 'university' showing this sense are administration, authorities, etc. These can be clarified in contexts like :

73. You are to refer to the university administration for an urgent matter.

74. The university authorities have issued a warrant to search the students' dormitory.

(xi) Scale : Every type of education can be gauged in a manner similar to anything that is measured by a graduated scale. So, in order to set any sort of education at a specific rate, we often use level to do the measure. This 'university' collocate, when contextualised, appears in a sentence like :

75. All the staff are educated to university level.

(xii) Memories : Memories mnemonic of by-gone times at university can be recalled by former students, leaners, teachers, professors, etc. This sense of 'remembrance' conjures up certain collocates such as days, life, years, etc., as in these contexts :

76. He is one of my close friends from university days.

77. To me, the university life was and still is the most beneficial and joyous period of time I've ever had.

78. I believe that the university years have elapsed like a streak.

(Al-Mawrid English-Arabic Dictionary; 1975; p: 915)

(xiii) Occupation : A university could occupy a vast area such as a town. This might happen due to the fact that a university alongside its affiliated colleges could stand on and extend over a whole town. This accounts for the fact that the whole town comes to be named after that sprawling university. Notice the following contextualised collocation :

79. Oxford is a university town in the United Kingdom.

2.1.4 [ Prep. At $+($ the $)+\mathrm{N}$ (= university) ] : This pattern accommodates a prepositional phrase with 'university' as pivotal element. We use 'at' if the routine regular work is at university; yet, if the reference is to the position inside the university, then 'in' is used; notice :

80. She is at university, studying engineering. 
81. Miss Barbara teaches English at the University of Wales.

Notice that both 'she' in (80), and Miss Barbara in (81) are engaged in a regular work, one is a student, and the other is a teacher. Moreover, the definite article 'the' should not be used. However, we use 'the' when we mention the university, followed by of-phrase functioning adjectivally describing university, being the name of that university.

The preposition 'in' is used in a context like this :

82. All the staff cannot be in the university at one time.

Here, 'in' means 'inside' the premises of the university. (Quirk 1983: 147)

3.1 Professor : The word "professor", often abbreviated as "prof", conveys the sense of "a teacher, especially a college teacher of the highest rank", as entered in (Webster's New World Dictionary; 1980; p: 341) In this sense, this noun operates within a collocational pattern like:

3.1.1 [ Adj + N (= professor) ] : In this structural pattern, certain adjectives may, very possibly, collocate with and precede "professor". As for the senses such collocates indicate, let's mention the following :

(i) Brilliance : Adjectives indicative of this sense include distinguished, eminent, etc., as instanced in :

1. Mr. Jackson is a very eminent professor.

2. Those men sitting on benches over there are distinguished professors.

(ii) Affiliation : Of the collocate adjectives with the noun "professor" are those that signalize the educational institution the professor belongs to and practices their career within. Such collocates include college, institute, university, etc., as clarified in sentences like :

3. University professors are supposed to be characterized by integrity and high knowledgeability.

4. Miss Janet is a well-known college professor.

Notice the collocates 'college', 'institute', 'university', etc., are not adjectives. Rather, they are nouns acting as modifiers designating the noun 'professor'.

(iii) Status : However, there are some adjectives that act in collocation with 'professor' displaying the status of such educators. Of such collocates are adjectives like assistant, associate, full, etc. These are contextualised in :

5. a. What does he do ?

b. He is an assistant professor at the University of Leeds. 
6. Don't you know that Mr. Brown has been promoted to full professor recently?

(iv) Category : The noun 'professor', as a profession, can be categorized as emeritus, visiting, etc. The following are contexts within which they occur :

7. I spent six months as a visiting professor at Brown University.

8. Murphy is professor emeritus of international relations at Wellesley College. (Cambridge Dictionary of American English; 2008; p: 273)

It is worth noting that the adjective 'emeritus' does not precede, but succeeds the noun 'professor' as a potential collocate.

(v) Specialty : Every professor is a specialist in a certain branch of knowledge or science; therefore, adjectives and nouns designating such a specialty may so readily collocate with the noun "professor". Adjectives and nouns such as history, law, medical, etc. can be detected in illustrative exemplars like :

9. She is an eminent history professor.

10. Being a law professor, Mrs. Jane explained the preamble fully.

(vi) Abstraction : People of knowledge including professors might, very possibly, be afflicted with mental mishaps, particularly in the process of time. So adjectives such as forgetful, absent-minded and even mad can collocate with and precede 'professor', as in :

11. He fitted perfectly the stereotype of the absent-minded professor.

12. It is unseemly for anyone to interrupt the proceedings of the lecture given by forgetful professors, let alone of those given by other professors.

3.1.2 [ N (= professor) + Prep. of ] : The noun "professor" can collocate with a succeeding preposition such as of ; within this collocational pattern, 'of ' is normally followed by an area of specialty, as we see in :

13. He is an eminent professor of English.

14. Mr. Allen is a famous professor of sociology.

4.1 Teacher: The noun teacher means : "One that teaches; especially one whose occupation is to instruct", as entered in (Webster's Intermediate Dictionary; 1972; p: 792). In this sense, "teacher" can be viewed in collocation with adjectives within a structural pattern such as :

4.1.1 [ Adj + N (= teacher) ] : In this collocational pattern, one may pinpoint certain adjectives preceding 'teacher' signifying a number of senses such as :

(i) Proficiency : Adjectives such as competent, good, inspired, skilled, qualified, experienced, etc. can be potential collocates, as in : 
15. His deeds are laudable as he is a competent teacher.

16. Being an inspired teacher, Mr. Brad has been awarded many prizes.

17. Experienced teachers should extend a helping hand to those who are still young.

18. We need to organize intensive courses so as to get well qualified teachers.

19. One learns a lot when they study under skilled teachers.

(ii) Incompetence : A teacher is not necessarily to be such competent, i.e. they could be bad, incompetent, as in :

20. She is a really bad teacher.

21. Incompetent teachers need to be engaged in refresher courses.

(iii) Gender : The teacher could be a man or a woman; therefore, adjectives indicative of gender can collocate with and precede 'teacher'. Of such adjectives are male, female, woman, etc., which can be contextualised in :

22. In the school are three male teachers and ten female teachers (ones).

23. That woman teacher is highly skilled in Arabic grammar.

(iv) Status : Teachers can be endowed with certain statuses within their career of teaching. Thus 'teacher' may operate in a collocational pattern preceded by collocates such as senior, head, chief, etc. These are further elucidated within contexts like these :

24. You may discuss the matter with the senior teacher.

25. The head teacher presided over the parent-teacher association.

26. You can have an audience with the chief teacher at the teachers' Union to hammer out an acceptable compromise.

(v) Affiliation : Every teacher must be assigned to a certain educational institution; thus, collocations involving collocates like college, primary (school), school, secondary (school), Sunday school, university, etc. can be detected in instances like these :

27. My brother, Ted, has become a college teacher.

28. Primary-school teachers are required to be gentle and sympathetic.

29. She is a highly qualified university teacher.

Notice that a number of collocates could co-occur with the noun- head 'teacher' as shown in (29) above where 'qualified' collocates with 'university teacher'.

(vi) Specialty : Areas of specialty often characterize teachers and these, however, account for the [ Adj+ N ] - collocates involving adjectives and nouns like language, subject, art, $\underline{\mathrm{EFL}}$ (= English as a foreign language),

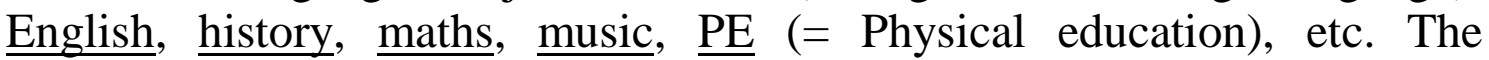
following are possible contexts of such collocates : 
30. Samantha is a competent language teacher.

31. That art teacher is a real connoisseur.

32. This subject teacher must be consulted on the issue.

33. EFL teachers should adapt well to the teaching of overseas students.

34. Music teachers ought to be talented with a highly sensitive ear.

(vii) Scope : Teachers, amongst other careerists, may work with variant scopes and spans. So 'teacher(s)' can collocate with certain scopeindicative adjectives like : part-time, full-time, etc., as in :

35. Cathy is well-paid as she is a full-time teacher.

36. Due to his numerous engagements, Mr. Ian is only a part-time teacher. (viii) Nature (of career) : At times, adjectives suggestive of the nature of a teacher's work may appear in collocation with 'teacher(s)'. So collocational patterns containing specialist, non-specialist, remedial, class/classroom, peripatetic, spiritual, etc. can be pin-pointed, especially in example sentences like these :

37. Is Mr. Jones a specialist teacher?

38. He might not be of use to you since he is a non-specialist teacher.

39. James is endowed with extensive knowledge, so he can serve as a well-qualified remedial teacher.

40. She is an optimal class teacher.

41. Mr. George is a peripatetic (country) teacher.

42. I wholeheartedly regard him as my spiritual teacher.

4.1.2 [ V + N (= teacher) ] : This pattern can frame a $[\mathrm{V}+\mathrm{N}]$ - collocation with 'teacher' as central element. Notice that the noun 'teacher' can act as direct object occurring immediately after such monotransitive verbs as

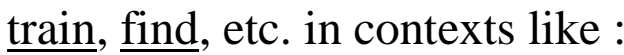

43. The Teachers' Union has organized a refresher course to train teachers.

44. She asked me to find her a competent teacher.

In (44) above, the verb 'find' is being used as a ditransitive verb with 'teacher' functioning as direct object, preceded by 'her' an indirect object. Moreover, within a similar pattern of collocations, 'teacher' can be framed up with following verbs such as teach something some-body, work with somebody, etc. These collocations can be exemplified in instances like :

45. I do look up to teachers working with pupils with special educational needs.

46. This teacher teaches precocious pupils.

4.1.3 [ $\mathrm{N}$ (= teacher $)+\mathrm{N}$ ] : This collocational pattern is another environment within which the noun 'teacher' falls. In this pattern, 'teacher' 
is followed by a noun. The nouns that may fall in collocation with 'teacher' may transmit the sense of :

(i) Knowledge : Nouns such as education, training and the like may follow 'teacher' in collocations such as :

47. The more the teacher education, the better the performance will definitely be.

48. Teacher training should be conducted periodically in the best interest of the teaching process.

(ii) Deficiency : Nouns indicating 'dearth' can also collocate with and follow the noun 'teacher'. The noun shortage can be seen in collocation with 'teacher' in an example sentence like :

49. This school sustains an acute teacher shortage.

(iii) Concern : The noun 'teacher' may, very possibly, collocate with and precede nouns such as association, $\underline{\text { union, }}$, etc. as contextualised below :

50. He is chairman of the Parent Teacher Association.

51. Janice is actually a member of the Teacher Union.

5.1 Lecturer : A lecturer is "One that gives a discourse or lecture before an audience or class; especially for instruction", as entered in (Webster's Intermediate Dictionary 1972; p: 426). There are certain collocates that precede the noun 'lecturer' in this sense. These, however include adjectives and nouns framed up in a collocational pattern like :

5.1.1 [ Adj + N (= lecturer) ] : Within this structural pattern, there are certain adjectives or nouns that collocate with and precede the noun 'lecturer'. These are restricted semantically as some of them give the sense of :

(i) Status : Adjectives indicative of this sense include assistant, junior, etc. These, however, tell of the stature a lecturer may attain; notice :

52. He is an assistant lecturer at the University of Sussex.

53. The junior lecturer over there is doing wonders these days.

(ii) Affiliation : A lecturer is definitely affiliated to a certain educational institution, be it college, university or else, as in :

54. Miss Kate is an eminent college lecturer.

55. He is such a competent university lecturer that students look up to him. Notice that in (54), above, more than one collocate can pile up so readily, i.e. a number of modifiers (premodifiers) may precede the noun. In (54), both 'eminent' and 'college' premodify and collocate with 'lecturer'. 
Cumulative premodifiers can also be detected in (55) where both 'competent' and 'university' fall in collocation with 'lecturer'.

(iii) Specialty : Certain adjectives and nouns can often be in collocation with the noun 'lecturer' as they must specialize in a field of knowledge or area of specialization. So one may come across collocates such as English, physics, chemistry, etc. in contexts such as :

56. The college is in dire need of English lecturers.

57. The chemistry lecturer in the lab is conducting some experiments.

In (57) above, the noun 'lecturer' is both preceded and followed by the collocates 'chemistry', a specialty-indicative collocate and 'in the lab', a location-indicative one that follows. So it is possible to come across clustering collocates.

(iv) Nature (of work) : To be more specific in the description of a certain lecturer, one may come up with descriptive premodifiers such as guest, visiting, etc., as exemplified in illustrative sentences like :

58. Mr. Thomas is now a visiting lecturer at the University of Michigan.

59. The guest lecturer has at last made the point clear to the audience.

(v) Seniority : One of the nomenclatures one might employ to describe a lecturer has to do with 'seniority'. In this regard, a lecturer can be described as principal, senior, etc., as in :

60. You are recommended to discuss this with the senior lecturer.

61 . Why don't you include the principal lecturer in the board?

5.1.2 [ N (= lecturer) + Prep. in + NP (= specialty)] : Within this collocational pattern, the noun 'lecturer' can, very possibly, occur in collocation with preposition "in" that, in turn, collocates with and is followed by a noun or noun phrase referring to the area of specialty. To exemplify such a colocation, let's cite the following instances :

62. Mr. Andy is a lecturer in German at Plymouth University.

63. As a lecturer in nuclear physics, Mr. Madison is now giving a lecture on atomic fusion.

6.1 Researcher : According to the (Dictionary of the English Language; 1983; p: 450) the noun 'researcher' is defined as "one who does research", i.e. one who does a careful study to discover correct information. This noun can co-occur with certain adjectives and nouns within a structural pattern such as :

6.1.1 [ Adj + N (= researcher) ] : Premodifiers include adjectives and/ or nouns with semantic restrictions in conjunction with the sense the noun 
'researcher' imparts academically. Premodifying collocating adjectives might signify :

(i) Prominence : Collocates of 'prominence'-sense include adjectives such as : eminent, experienced, leading, competent, etc., as instanced in contexts such as :

64. We do admire eminent researchers who do exceptional research.

65. Experienced researchers ought to be assisted financially and morally.

(ii) Specialty : Any researcher must research into a specific field of study; therefore, adjectives indicating such specialties co-occur with and precede the noun 'researcher'. These include collocates like medical, cancer, educational, social, academic, etc. which can be signalized in contexts like :

66. Medical researchers have come up with diagnostic recommendations.

67. The cancer researcher that I know is a relative of John's.

68. Being an academic researcher, you are required to follow the procedures.

69. Such a faux pas needs to be researched into by social researchers.

70. Janice is a leading educational researcher worthy of esteem by all and sundry.

It is worth noting that collocates can, very possibly, pile up as in (70) above where 'leading' and 'educational' are stringed together in collocation with 'researcher'.

(iii) Age : Adjectives designating the age of someone, let alone a researcher, can co-occur with and precede 'researcher'. Such adjectives as young, old, middle-aged, etc. can occur in collocation with 'researcher' in examples like these :

71. He is the youngest researcher I've ever known.

72. The old researcher said : "It is never too old to learn."

It is possible, though, that a collocating adjective be used in the comparative or even in the superlative degree. This, however, can be viewed in sentence (71) above. 'Young' and 'old' are referred to as gradable adjectives on account of the fact that such adjectives can be compared.

(iv) Level : A researcher could be assigned to a certain level of study and thus the word 'researcher' may, at times, co-occur with attributive collocates. Such adjectives are undergraduate, post-graduate, postdoctoral, etc., which are used in contexts such as :

73. After college, she spent her life as a post-graduate researcher.

74. Post-doctoral researchers abroad are in desperate need of subventions. 
(v) Seniority : Researchers in general can be categorized as chief or senior, and this necessitates that 'researcher' be in collocation with such adjectives, as in :

75. That handsome young man over there is the chief researcher at the institute.

76. The senior researcher at the college will be a beneficial consultant to you.

(vi) Priority : Adjectives collocating with the noun 'researcher(s)' can impart the senses of 'earliness' as well as 'lateness'. So the adjective early, or late can premodify and be in a potential collocational pattern with 'researcher', as in :

77. She based her work on that of earlier researchers.

78. Late researchers opine that safety measures be strictly imposed.

(vii) Allegiance : Researchers could have certain allegiance. With this sense, we may see collocations involving adjectives such as independent, academic, etc. in example sentences like these :

79. To be an independent researcher gives one some leeway.

80. Is Jennifer an academic researcher?

6.1.2 [ Np (= group/ team $)+$ of $+\mathrm{Npl}$. (= researchers $)]$ : The plural noun "researchers" can be in collocation with a preceding partitive noun phrase with "a group" or "a team" in collocational contexts like :

81. A group of teachers will attend the scientific conference next week.

82. These results have been arrived at by a team of researchers.

6.1.3 [ $\mathrm{N}$ (= researcher) $+\mathrm{V}$ ] : This collocational pattern holds within the noun 'researcher' which can be followed by verbs such as investigate something, work in/_on something, etc. Within such a pattern, the noun 'researcher' occupies the position of subject and the verb that collocates with and succeeds it is a transitive verb, i.e. it requires a direct object to follow. Such collocational patterns are exemplified in :

83. These researchers are investigating some problematic controversial topics.

84. The researchers worked on the biochemistry of learning.

Moreover, within the same collocational pattern, one may come across the noun 'researcher(s)' in collocation with another set of transitive verbs including believe something, think something, claim something, note something, suggest_something, say something, etc. These verbs are either mental-activity verbs or verbs of utterance. To signalize the collocations, let's adduce the following exemplars : 
85. One of the researchers believed that the goal is within reach.

86. That eminent researcher suggested that they conduct a field work.

87. Experienced researchers have claimed that the experiment is achievable.

88. The researcher on the committee thought that the hypothesis is feasible.

89. I think that the researcher said something I could not grasp.

One can elicit that collocations may readily cluster around the noun at issue. In sentence (86), for instance, we see that 'researcher' is preceded by the adjective 'eminent' and at the same time, it is followed by the verb 'suggest'. The same clustering elements can be viewed around 'researcher' in sentence (87) above, where 'experienced' precedes 'researcher' whereas it is followed by the verb 'claim'. In (88), 'researcher' is preceded by the determiner 'the' and followed by the modifying prepositional phrase 'on the committee' which, in turn, is followed by the collocating verb 'think'.

Besides, the noun 'researcher' can collocate with and precede verbs such as show something, conclude something, etc., as clarified in such contexts as :

90. The researchers have concluded that further studies are needed.

91. One of the researchers showed that the recommendations were practicable.

6.1.4 [ N (= researcher $)+$ Prep(in/on $)+\mathrm{NP}]:$ This structural pattern is an environment of the noun "researcher(s)" in collocation with a prepositional phrase involving nouns such as field, team, committee, etc. Such collocations are contextualised in :

92. The book is written by experts who are well known as researchers in the field.

93. You can count on all the researchers on the team.

94. The researchers on the committee are all trustworthy.

Notice that the preposition used could either be 'in', or 'on' in conformity with the noun that follows.

7.1 Supervisor : This noun is entered in (An English Reader's Dictionary; 1976; p: 439) to mean "one that watches and directs (work, workers, researchers, an organization, etc.)". The sense of the word as such necessitates a collocational pattern such as :

7.1.1 [ Adj + N (= supervisor) ] : The adjectives that collocate with and precede 'supervisor' are semantically restricted to certain senses. Of such senses, let's enumerate : 
(i) Rank : Supervisors, as people of resource and experience, can fall within certain ranks. Therefore, adjectives such as chief, senior, etc. are potential collocates, as in :

95. He is the chief supervisor on whom you can rely for your thesis.

96. Of all the supervisors, you can consult the senior supervisor, Mr. McArthur.

(ii) Specialty : Areas of specialty may characterize the supervisor's work. With this restriction of sense, adjectives and modifying nouns such as shift, project, production, technical, research, etc. can be in collocation with 'supervisor', as instanced below :

97. Take care! The shift supervisor is due here in seconds.

98. The project supervisor has rejected the plan all together.

99. You need to comply with the research supervisor so that your research would be letter-perfect.

100. This production-line was ordered to be stopped by the production supervisor.

101. The technical supervisor has made the point crystal-clear.

7.1.2 [ V + N (= supervisor) ] : With this collocational pattern, the noun 'supervisor' can co-occur with and follow verbs such as act as etc., as shown below :

102. Carlos acts as a supervisor in an important research centre.

103. You may take recourse to him as he works as a supervisor in one of those advisory boards.

7.1.3 [ Prep (= under) + Det. $+\mathrm{N}$ (= supervisor) ] : This pattern frames up the collocations "under a/ the supervisor", as in :

104. The people working under that supervisor are all suburban.

105. To work under a supervisor is highly recommendable.

8.1 Tutor : As entered in (Cambridge Dictionary of American English; 2008; p: 945) the noun "tutor" means "a teacher paid to work privately with one student or a small group". In this sense, 'tutor' operates in the framework of a collocational pattern like :

8.1.1 [ Adj + N (= tutor) ] : In collocation with "tutor" there are certain adjectives that are semantically consistent. Some of such attributively used adjectives have the meaning of :

(i) Excellence : Adjectives suggestive of 'excellence' include good, experienced, professional, etc., as exemplified in : 
106. Being an experienced tutor, Mr. Sam has become the centre of attention.

107. Good tutors are a rarity these days.

108. A professional tutor is one who makes a profession of their tutorship.

(ii) Privacy : The essence of tutorship is 'privacy'; therefore, 'tutor' can pattern with adjectives like personal, private, etc., in contexts such as :

109. As a private tutor, he is widely known to so many.

110. My personal tutor has given me a lot of homework assignments.

(iii) Scope : A tutor may perform his/ her career within a certain time span. With this sense, adjectives such as part-time, full-time, etc. may precede as potential collocates, as in :

111. He is a part-time tutor at college.

112. As a full-time tutor, he has so little time for others.

(iv) Status : With the meaning of "status" as "a person's legal, social, or professional position in relation to others" in (An English Reader's Dictionary; 1967; p: 425), we see that the noun 'tutor' may collocate with and follow status-signifying adjectives, such as assistant, senior, etc. in exemplars like :

113. The assistant tutor that I know is really competent.

114. I believe that the senior tutor is your last resort; he can help you out.

(v) Affiliation : Tutors may be assigned to a college, school or university and therefore such modifying nouns normally collocate with and premodify 'tutor', as in :

115. The college tutor has held a tutorial with the students' parents.

116. He received a phone call from the school tutor.

117. One of the university tutors put forward a proposal to ameliorate the standard of graduates.

In (117) above tutor means "a university teacher who guides the studies of a number of students", as entered in (Ibid: 471).

(vi) Specialty : The majors of tutors could involve words like art, English, etc., as adduced in contexts like these:

118. The art tutor next door is a true gourmet.

119. In order for you to gain mastery of English, you need to consult the English tutor.

8.1.2 [ V + N (= tutor) ] : The [V + N]- collocational pattern could be host of verbs like act as, work as, etc. preceding 'tutor' to refer to the job of 'tutor', as in : 
120. His wish to act as tutor has, at last, come true.

121. To work as a tutor requires patience and diligence.

8.1.3 [ N (= tutor) + Prep. to + NP ] : This structural collocational pattern frames up the noun 'tutor, the preposition 'to' and a following noun or noun phrase, as in :

122. Roger Ascham, tutor to Queen Elizabeth, is an erudite man.

9.1 Student : The noun 'student' means "a person who is studying at a school, college, or university", as entered in (Cambridge Dictionary of American English; 2008; p: 869) With this sense, 'student' normally patterns with attributive adjectives within a collocational framework like :

9.1.1 [ Adj + N (= student) ] : This collocational pattern can accommodate certain adjectives with senses congruent with the sense of 'student'. The adjectives premodifying 'student' may transmit the sense of:

(i) Standard : Students can naturally be designated according to their standard of study with adjectives like : good, brilliant, diligent, studious, industrious, perseverant, conscientious, excellent, etc., as illustrated in :

1. The dean opened his inaugural saying : "Distinguished professors, conscientious students! Good morning".

2. We all aim at raising the standard of already good students.

3. It is incumbent upon us to offer encouragement to perseverant students.

4. This is one of my brilliant students.

5. That student in uniform is one of the best students the college has ever had.

Notice that collocates can, very possibly, cluster around 'student', as we see in (5) above, where the initially-occurring 'student' is collocating with a demonstrative 'that' and succeeded by 'in uniform', a prepositional phrase functioning adjectivally. The second-occurring 'student' is preceded by the adjective 'good' in its superlative-degree form 'best'.

(ii) Affiliation : Students can have a certain affiliation to a school, college, university, institute, etc., therefore, collocations like these are quite possible :

6. College students are often advised to wear a uniform.

7. He is now a university student at the University of Bangor.

8. Those young men sitting on the lawn are vocational institute students. Though 'institute' in (8) above is in collocation with 'student', another collocate can also co-occur to be a potential collocate such as 'vocational'. 
(iii) Stage : Naturally students are at variant education-levels in the course of the undergraduate study. This, however, accounts for 'student'collocations involving compound adjectives attributively used such as first-year, second-year, third-year, fourth-year, or even fifth-year (as is the case with the students of medicine). Such collocational contexts are illustrated in :

9. First-year students are holding an ice-breaking party on campus.

10. The fifth-year (medical) students are having an anatomy class with professor David at the moment.

Notice that collocates could readily pile up as we see in (10) above where the adjective 'medical', for instance, can be appended as a semantic prerequisite.

Attributive adjectives above are often used in British English while in American English, these are replaced by first-grade, second-grade, thirdgrade and so on. All these collocations, however, can be substituted for by synonyms such as freshmen (= first-year students), sophomores (=secondyear students), juniors (= third-year students) and seniors (=fourth-year students).

It is worth noting that 'sophomore', which means "a person in second year of college, etc." is American usage as entered in (An English Reader's Dictionary; 1967; P: 412).

(iv) Level : The level of students necessitates collocates such as graduate, undergraduate, postgraduate, etc., which are elucidated in such contexts as :

11. "All postgraduate students, please, stand up" ! said the vice-dean.

12. We do need to engage undergraduate students in after-class activities.

(v) Diplomas : Occasionally students are referred to by the diploma they are working for. In this case, collocates such as M.A. (= Master of Arts), doctoral, Ph. D. (= Philosophae Doctorate/ Doctor of philosophy), B.A. (=Bachelor of Arts), B.Sc. (= Bachelor of science), etc. are potential ones, as in :

13. This is a seminar held by M.A. students.

14. Ph.D. students are required to participate in this scientific conference.

15. They are holding a refresher course for B.Sc. Students so as to acquaint them with lab safety measures.

(vi) Age : Like all people, students can be described by their age; so one may come across attributive collocates such as young, middle-aged, old, mature, etc. in contexts like : 
16. He studied metallurgy as a mature student, having spent ten years working in a foundry.

17. Young students ought to cudgel their brains to accumulate as much knowledge as they can while they are still young.

(vii) Specialty : As usual, students might specialize in certain areas of specialty or fields of study. With this sense, attributive adjectives and premodifying nouns can precede 'student(s)'. Of these, let's mention engineering, history, law, medical, etc., as exemplified in below :

18. Engineering students must learn how to put theory into practice.

19. These law students are given intensive courses in International law.

20. Frankly speaking, medical students are supposed to be inured to boldly tackle cases of emergency.

(viii) Location : Centres of study and education are interspersed here and there, whether inside one's homeland or abroad. Students, therefore, can be referred to by their places of study. With this sense of location, we may have as attributive collocates words like overseas, local, etc., which can be contextualised below :

21. It goes without saying that overseas students should enroll in a language course.

22. Local students have launched a protest demonstration demanding the immediate release of one of their arrested classmates.

9.1.2 [ $\mathrm{N}$ (= student $)+\mathrm{N}$ ] : This collocational pattern can snugly host certain nouns in collocation with 'student'. Such nouns can convey the meaning of :

(i) Specialty-to-Be : With this meaning, nouns such as nurse, teacher, doctor, etc. can follow 'student' in collocations like :

23. Student teachers need to be provided with class-management strategies. 24. It is necessary that student nurses get engaged in real-life circumstances at hospitals.

(ii) Amount : Within the same collocational pattern, 'student' could be followed by noun collocates indicative of 'amount' such as numbers, population, etc., as in :

25. Student numbers at the college have increased by 25 per cent.

26. The living standard of student population should be improved sooner rather than later.

(iii) Bygone Time : Memories from 'school', 'college', or 'university' days can, sometimes, be evoked. Such memories can be recalled by mnemonic collocates such as days, years, life, etc., as exemplified in contexts such as : 
27. She travelled a lot in her student days.

28. He thoroughly enjoyed student life when he was a college student.

29. I still remember my classmates from student years.

It is to be noted that 'life' is not necessarily to be reminiscent; rather it could collocate with 'student' to indicate present-time situations, as in :

30. I really enjoy student life. It is somewhat a carefree life.

(iv) Subvention : Students, being entitled to subvention, due to the fact that they are mostly jobless, do need to be financially supported throughout their study. As for such meaning, we can come across noun collocates such as grant, loan, etc. which are clarified in contexts like these :

31. She had to take out a student loan to help her through college.

32. I think the student grant is an inevitable aid to students to enable them to pursue their studies conveniently.

(v) Accommodation : Students living in outlying areas far away from the educational institutions in which they study need to be accommodated in term time. The sense of 'housing' during term time necessitates the use of collocates such as accommodation, dormitory, etc., as exemplified in :

33. The government should provide student accommodation for all those who are entitled to it.

34. The student dormitory should be well equipped with the necessary conveniences.

(vi) Leeway : Being in a democratic society, students might, very possibly, get involved in certain activities including marches or processions organized so as to demand certain legitimate rights and privileges, Moreover, they might launch a protest against certain malpractices and fallacies. This 'leeway' margin can conjure up collocates such as demonstration, protest, unrest, etc., as we may view or hear in contexts such as :

35. The student demonstrations continued into the third successive day.

36. Last week James and Alice took part in a student demonstration.

37. The university administration has positively responded to student protests.

38. The riot police were summoned to quell the student unrest yesterday.

9.1.3 [ as a $+\mathrm{N}$ (= student) ] : This collocational pattern frames up the noun 'student' with the preceding capacity-indicating marker "as a". This marker, i.e. "as a" means "in the role or function of" as entered in (Webster's New World Dictionary; 1980; p: 24) \& (Quirk 1983: 159). Here in below are possible contexts hosting "as a" :

39. She first went to London as a student. 
40. As a brilliant student, Synthia won a scholarship to Queen's College, Cambridge.

Notice that "as", above, functions as preposition.

10.1 Examination : The noun 'examination', which is often abbreviated as 'exam', refers to "a test of a student's knowledge or skill in a particular subject," as entered in (Cambridge Dictionary of American English; 2008; p: 289). With this sense, "examination" falls snugly into a collocational pattern such as :

10.1.1 [ Adj $+\mathrm{N}$ (= examination) ] : In this pattern, certain adjectives can fill in the prenominal position; thus together with the noun 'examination' constitute a unitary unit. Such collocates, however, may convey the meaning of :

(i) Difficulty : An examination could be difficult, hard, stiff, etc., as in :

1. The stiff (entrance) examination removes 60 per cent of prospective students.

2. You are supposed to study as hard as you can so as to pass this difficult examination.

(ii) Ease : An examination is not necessarily to be hard, yet it could be easy, as we see in :

3. I can pass this easy examination with high mark.

(iii) Category : Examinations are of several categories in terms of the purpose behind which they are set. The collocates with 'examination' could be either nouns modifying the noun head or adjectives. These, however, are words like entrance, matriculation, selection, admission, competitive, etc., as in :

4. In order for you to get admission into college, you must take and pass the entrance examination.

5. The matriculation examination is not going to be so easy.

6. Students should emulate honestly with one another in the competitive examination.

7. The selection examination must be managed with the utmost degree of integrity and fairness.

(iv) Temporal Appointment : Examinations are assigned in accordance with certain schedules, not haphazardly. So they may be termed by these collocates : end-of-term, mid-term, end-of-year, final, mid-year, etc. which are best explicated in contexts like these :

8. He has just completed his final examinations at London University. 
9. You should make it through the end-of-year examination.

10. She passed her mid-term examinations with flying colours.

11. The end-of-term examinations are scheduled for next week.

(v) Orientation : An examination may be differently oriented. With this 'orientation' sense, the noun 'examination' normally collocates with and follows adjectives like external, public, formal, professional, etc., as in :

12. One of the teacher's principal duties is to prepare students for external examinations.

13. Last year's public examinations were rather difficult.

(vi) Level : There are a number of levels on account of which examinations are given. So 'level'-designating adjectives are potential collocates with 'examination'. They are A-level, B-level, GCSE (= The General Certificate of Secondary Education), etc., as exemplified in :

14. Jane got a good mark in the A-level examination.

15. Since you have passed the GCSE examinations, you are now up to the standard required for admission into college.

(vii) Type : In view of the essence of the exam-content, we can categorize examinations as multiple-choice, oral, practical, written, viva voce, etc. Below are example sentences exemplifying such collocations :

16. Multiple-choice examinations require accurate and specific answers.

17. I'd rather take an oral examination than a written one.

18. I shall never forget that viva voce examination 1 once had at college.

It is to be noted that "viva voce" means "expressed orally" as an adjective and it could be used as a noun meaning "an examination conducted by spoken communication", as entered in (Al-Mawrid English-Arabic Dictionary; 1975; p: 1034).

(viii) Institution : It is axiomatic that examinations be described according to the educational institutions organizing them. So we may come across

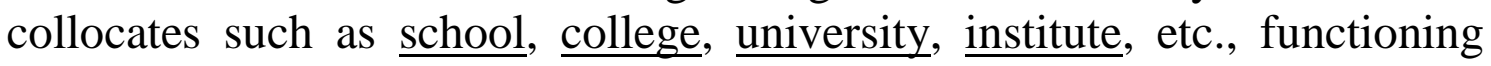
adjectivally, as we see in example sentences like :

19. School examinations vary from one school to another.

20. You must prepare so well for the college examinations.

10.1.2 [ V + N (= examination) ] : Within this pattern of collocations, one can view certain verbs in collocation with the noun 'examination'. These verbs precede as potential collocates with senses such as :

(i) Perseverance : This sense can be transmitted by verbs like : Prepare for, revise for, study for, etc., as instanced in collocations such as : 
21. Students may revise for the examination in the Central Library.

22. The teacher advised his students to prepare for the examination long enough before it is due.

23. "Study for your examinations as hard as you can, "the professor told the audience.

(ii) Participation : Some 'examination'-collocating verbs pivot around the sense of 'participation'. Such verbs include enter for, participate in, do, sit, $\underline{\text { take, }}$, etc. which are contextualised in collocations like :

24. Students may enter for both examinations.

25. She will take her (professional) examinations later this year.

26. I had my fourth-year students sit the (grammar) examination yesterday.

It is to be noted that some other collocates could, very possibly, intervene, i.e. these may co-occur with 'examination', yet they snugly fit between the verb and the noun 'examination'. This can be observed in (25) above, where the collocate 'professional' intervenes between 'take' and 'examination'. Besides, the determiner "her" also intervenes between "take" and "examination", but it precedes both the noun and the pre-modifying adjective. The same is true for (26) above, where 'grammar' collocates with and precede 'examination'. The verb 'sit' in collocation with 'examination' is normally used in British English. In this sense, "sit" is a transitive verb meaning "to take (an examination)", as in : "Pupils are required to sit nine subjects at GCSE".(http://en.Oxforddictionaries.com).

(iii) Performance : The noun ;examination' could collocate with verbs indicative of the 'performance' sense . Performance may either be :

(1) Good performance, and as such verbs like do well in, pass, etc. can cooccur in collocation with 'examination', as illustrated in exemplars like:

27. a- How did you do in the examinations?

b- I did well in the examinations.

28. I have already passed my examinations with high marks. or the performance may turn out to be :

(2) Bad performance : With this sense, we may come across verbs like do

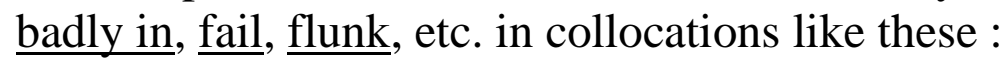

29. She studied hard but (she) failed the examination nevertheless.

30. Sandra did badly in the examination last week.

31. Some of the students flunked the (physics) examination.

The verb 'flunk' means "fail as in schoolwork" in colloquial English as entered in (Webster's New World Dictionary; 1980; p: 169). 
(iv) Re-attempt : Students might fail one examination, yet they re-take or re-sit the examination some other time in hope of success. This recurrence of attempt with those verbs underlined can be exemplified in examples like:

32. Don't worry ! There is always tomorrow. You can resit the examination next week.

33. The students are retaking the (biology) examination at the moment.

(v) Organization : Any examination ought to be formatted and put into effect. This sense requires the verb set to indicate the efforts exerted in the implementation of the examination; notice :

34. A panel of experts set the examinations for the postgraduate students.

Often, though, the verb set could be used in a passive construction, as in :

35 . The examinations are set by individual teachers.

In (35) above, set collocates with, but follows 'examination(s)' due to the re-arrangement effected by the passive transformation.

(vi) Management : Examinations, in order for them to be managed well and be within full control, need to be well administered and optimally invigilated. Therefore, verbs like administer, invigilate, etc. can be potential collocates in example sentence like these :

36. We need to administer the examinations in the best possible way.

37. To invigilate the examinations nowadays is not an easy task.

(vii) Scoring : Some other collocates could be relevant to the sense of 'scoring'. Verbs indicative of this sense are mark, score, etc. which are instanced in :

38. The teacher has to spend her weekend marking all the examinations (= tests) .

39. The teachers have scored the examinations (= tests) out of 20.

10.1.3 [ $\mathrm{N}$ (= examination) + N ] : The noun 'examination' may collocate with, but precede some noun collocates. Such nouns may vary in meaning. Some of them convey the meaning of :

(i) Place : Examinations are always held in certain places such as hall(s), room(s), etc., so such words collocate with, but follow 'examination', as in :

40. The dean has conducted an inspection tour to get acquainted with the examination halls.

41. The examination rooms are equipped with all the necessary conveniences. 
10.1.4 [ N (= examination) + in + NP ] : The noun 'examination' can have as an immediate collocate the preposition in which normally follows in an example collocational context, as in :

42. He failed his examination in English grammar.

(i) Format : Examinations can take certain formats as regards the way they are taken as well as the content involved. With this 'format' sense, we may view collocates such as paper, question, etc., as shown in :

43. The professor proposed that the examination papers be signed.

44. What do you think about the examination questions ?

(ii) Material : Any examination must involve some material in which students are examined. So the syllabus prescribed constitutes part and parcel of the examination set by teachers, educators, lecturers and other specialists, as we see in :

45. The lecturer has almost covered all the examination syllabi.

Notice the word 'syllabus' has two plural forms : syllabuses and/ or syllabi.

(iii) Aftermath : The aftermath of any examination includes the outcome of the examination students often apprehend. With this sense, collocates such as grades, marks, results, etc.,can, very possibly, co-occur with 'examination'. The following are contexts within which such collocations fit:

46. The examination marks prove, beyond any doubt, that students' standard is on the rise.

47. We are awaiting the examination results on pins and needles.

It is to be noted that "grades" is almost synonymous with "marks", but it is used in American English.

(iv) Qualification : Occasionally, participation in an examination requires certain qualifications. So a participant needs to be a candidate, as in :

48. The examination candidates are required to refer to the head office.

(v) Pay : Some examinations cannot be taken unless the candidates pay a certain fee; so this collocate can be observed in an example like this :

49. You are supposed to pay the examination fee as quickly as possible.

(vi) Documentation : Examinees are often granted certificates certifying the fact that they have already taken and passed the examination; so certificate is often a potential collocate, as seen in this context :

50. They desperately need some confirmations including examination certificates. 
(vii) Prosperity : Examination results are often awaited anxiously and eagerly; this, however, means that success is the ultimate objective aspired for; notice :

51. Nothing ever is tantamount to one's examination success.

(viii) Strategy : Any examination is supposed to be formatted within a certain technique in order for it to be up to the standards strictly required. This collocate can be in collocation with 'examination' in a context like this:

52. I think that the examination technique pursued is the best so far.

11.1 Test : This academic term means "a set of questions or practical activities that show what someone knows or what someone or something can do or is like", as entered in (Cambridge Dictionary of American English; 2008; p: 905). With this sense the noun 'test' can fill a slot in a pattern of collocations such as :

11.1.1 [ $\operatorname{Adj}+\mathrm{N}(=$ test $)]$ : There are certain adjectives that collocate with and precede 'test' and these adjectives can transmit the sense of :

(i) Intricacy : Adjectives signifying the 'intricacy' sense include demanding, difficult, gruelling, etc., which are contextualised in instances like :

53. Great effort and patience are required to do a demanding test.

54. We ought to be highly experienced with difficult tests.

55. Jane spent many laborious hours preparing for the gruelling test that she was supposed to take.

(ii) Ease : Contrary to intricacy, we may see adjectives such as easy, simple, etc. indicating 'easiness' of a test. These are often viewed in illustrative example sentences such as :

56. I can do these easy tests hands down.

57. You don't have to be so anxious about it; it is only a simple test.

(iii) Orientation : Tests should be oriented towards the amelioration of certain aspects of study so as to upgrade the standard required. So a test can be fair, good, objective, subjective, etc. Thus examples like the following can serve as good slot-fillers for such adjectives; notice :

58. This type of exam does not provide a fair test of the student's knowledge.

59. Objective tests are often given priority over subjective tests.

60. We should always be intent on good tests in order to come up with good results. 
(iv) Type : There are a number of types of tests including listening, oral, practical, written, etc. Therefore, the noun 'test' may fall within a collocational pattern with such adjectives attributively used. Below are a few contexts in which they fit :

61. Conversationalists had better be subjected to listening tests.

62. Oral tests are feared most by overseas students.

63. Practical tests are the best that assess students' performance.

64. The majority of students sit written tests at colleges.

(v) Content : Tests are laid out in a way that may involve a certain context by which students' real standards are properly assessed. With the 'content' sense, adjectives such as multiple-choice, cloze, etc. are potential collocates exemplified in :

65. Multiple-choice tests, though hastily done, yet they require the testees to be on full alert.

66. Cloze tests require the testees to be endowed with the ability to fully understand the contexts of words as well as to have a huge repertoire of words.

(vi) Purpose : Behind every test there must be a set purpose pursued so as to achieve a certain goal. In this 'purpose' sense, one may come across a collocate such as placement, as contextualised in :

67. He scored well in the placement test and was put in the most advanced class.

(vii) Faculty : Tests are often mental-and-physical-power gauging. This, however, necessitates the use of collocates such as achievement, aptitude, endurance, intelligence, IQ (= Intelligence Quotient), language, memory, mental, proficiency, spelling, driving, etc. These collocates are instanced in contexts like :

68. The recruits were put through a week of gruelling endurance tests.

69. The aptitude test aims at assessing inherent ability.

70. Cadets are expected to pass the endurance test.

71. In order for them to get admission into the diptomatic corps, the applicants must get through the intelligence test.

72. The IQ test is a psychological measure of a person's intelligence quotient.

73. Overseas students should enroll in a language test.

74. They must sit the memory test before they are given the go-ahead to move on to the next stage.

75. Mental tests entail intensive refresher courses.

76. Postgraduate candidates are now taking the proficiency test. 
77. Martha did not prepare well for the spelling test, so she failed.

78. To get a driving licence, you need to pass the driving test.

(viii) Elimination: One of the purposes behind setting a test is to eliminate those who are disqualified. This 'elimination' sense requires a collocate such as screen to co-occur with and precede 'test', as elucidated in :

79. Three actors out of a hundred were chosen from the screen test.

11.1.2 [ V + N (= test) ]: This pattern of collocation could be filled in with certain verbs having the meaning of :

(i) Participation : Verbs that signify this sense are do, sit(for), take, etc., which can be contextualised in these sentences :

80. I took my driving test last week.

81. Will you, please, tell me when we are supposed to sit (for) the test?

82. A number of specialists have done the tests properly.

Notice that in (80) above, 'test', not only collocates with "take", but with a determiner 'my' as well as 'driving', an adjectivally used noun.

(ii) Success : Like an examination, a test needs to be passed; therefore the verb pass usually co-occurs with and precede 'test'. In this collocation, the verb "pass" is a transitive verb followed by "test" functioning as direct object, as shown in :

83. He was put to a hard test, but he managed to pass that test.

(iii) Failure : A test is not necessarily to be passed, it could, very possibly, be flunked. With this sense, the verbs fail, flunk, etc. can be detected as potential collocates, as in the following contexts :

84. Unfortunately, many candidates failed last week's test.

85. Catherine flunked the test quite unexpectedly.

(iv) Administering : Tests are often administered by those in charge. This sense necessitates the use of verbs such as administer, give, set, etc., as in:

86. The board of specialists administered the test in conformity with the latest techniques.

87. To give objective tests undoubtedly contributes to the production and creation of lofty-minded personages.

88. They set such tests to meet the requirements of overseas students.

(v) Evaluation : When tests are taken by learners, students or other candidates, they need to be scored. They 'scoring' sense entails the use of the verb mark as a potential collocate and it can be exemplified in :

89. I think scorers will mark these tests out of twenty. 
11.1.3 [ $\mathrm{N}(=$ test $)+\mathrm{N}$ ] : This structural pattern may involve the noun at issue 'test', followed by another noun as an immediate collocate. Such a noun can convey a certain sense; notice :

(i) Outcome : This sense can, very possibly, correspond to 'test' in that every test is often awaited as far as the outcome is concerned. Thus we may come across the noun result(s) in collocation with 'test', as contextualised in:

90. When will the test results be officially declared?

91. The test results prove that the students' standard is above par.

(ii) Circumstance : A test may be surrounded by certain circumstances being an eventive noun like 'party', 'concert', etc., as spotted in Quirk (1983: 173) Therefore, the noun conditions falls in with 'test' as a potential collocate in a context like :

92. As a final practice for the exam, they had to write two essays under test conditions.

(iii) Content : Every test must consist of questions posed to testees to be done. Moreover, the majority of tests are conducted on sheets of paper, i.e. the questions of a test are put on paper. With this 'content' sense, 'test' can be viewed in concomitance with collocates like paper, questions, etc., as signalized in contexts such as :

93. The test questions are so hard that they require one to cudgel their brains.

94. The testees are required to hand in the test papers as the time allotted is almost up.

11.1.4 [ Prep (= in) + Def/ Indef. Art. + N (= Test) ] : This pattern serves as an occasional slot containing the preposition 'in', followed by either a definite or indefinite article plus the noun 'test'. It is worth mentioning that another collocate could intervene between the article and the noun 'test'. Such intervening collocate might involve a noun designating the subject in which testees are tested; notice :

95. Some of the questions in the (history) test were rather difficult.

11.1.5 [ N (= test) + Prep. in ] : This pattern hosts the noun 'test', but this time, it is followed rather than preceded by 'in'. What follows 'in' mostly indicates the topic in which the testees are tested. This collocation is contextualised in :

96. The students are supposed to take a test in mathematics shortly.

11.1.6 [ N (= test) + prep. on ] : This collocational structure shows that 'test' can be followed by the preposition 'on', when the topic tested on is being 
referred to deliberately and rather formally, as explicated in (Ibid: 163). The following is context highlighting the case :

97. They won't get admission unless they have passed a test on the French Revolution.

12.1 Quiz : It is a noun meaning "a short, informal test", as entered in (Cambridge Dictionary of American English; 2008; p: 702). With this sense, 'quiz' fits in with a number of potential collocates within a pattern of collocations such as :

12.1.1 [ $\operatorname{Adj}+\mathrm{N}$ (= quiz) ] : There are certain adjectives that co-occur with and precede the noun 'quiz'. Of these are film, general-knowledge, sports, etc., which can be contextualised in exemplars like these :

98. Our teacher had us take a general-knowledge quiz yesterday.

99. Last week's sports quiz was really typical.

12.1.2 [ V + N (= quiz) ] : In this pattern, 'quiz', co-occurs with and follows a transitive verb; thus it acts as direct object. The verbs that collocate with 'quiz' may transmit the sense of :

(i) Participation : Any quiz cannot be effected without those who opt for taking it; therefore, verbs indicative of this sense are potential collocates. Verbs like enter, take part in, etc., may collocate, as exemplified in :

100. Many students are expected to enter the quiz organized by a galaxy of experts.

101. Some postgraduate students intend to take part in the quiz supposed to be held at 8:30 a.m.

(ii) Organization : Quizzes cannot take effect unless they are organized by the institutions or specialists concerned. Therefore, verbs such as hold, organize, etc., can co-occur with and precede 'quiz' in contexts like :

102. The lecturer held a quiz so as to assess students' faculties.

103. We ought to put our heads together to organize an optimal quiz.

Notice that an adjective could be inserted between the verb and 'quiz'. This, however, indicates that series of collocates can be in immediate concomitance with 'quiz'.

(iii) Info. Gathering : It is axiomatic that a quiz can only be formatted when information is gathered. With this sense, the verb compile can co-occur with and precede 'quiz' in a context like :

104. We need to compile a quiz to meet the standards required. 
(iv) Achievement : One should aspire to achieve the result intended when they take a quiz. In this regard, the verb win can be in collocation with 'quiz' in a context such as :

105. My ultimate goal is to win the quiz at all costs.

12.1.3 [ N (= quiz) + N ] : One of the senses 'quiz' may convey is "a set of questions about a particular subject that people try to answer as a game or competition", as entered in (Merriam-Webster Dictionary Online). This sense necessitates certain collocates, i.e. nouns occurring after 'quiz'. These, however, give the sense of :

(i) Contest : Nouns in collocation with 'quiz' can transmit the sense of emulation to win scores in a game, show, competition, programme, etc. Contexts that may serve to clarify such collocations are :

106. Many students took part in the quiz competition in a heated event to score highest points.

107. The quiz game is a good opportunity for talented students to assert themselves.

108. Great efforts have been exerted to prepare for the quiz programme.

109. The quiz show will be televised live tonight.

(ii) Appointment : Such quizzes could be held at specific times; therefore temporal nouns such as evening, night, morning, etc. can be potential collocates within contexts like these :

110. The club has a quiz night every Wednesday.

111. The quiz evening has polarized a number of the intelligentsia.

(iii) Content : Any quiz consists of questions to be posed to those quizzed. Thus a collocation involving question(s) is quite familiar in a context like :

112. It seems that the quiz questions are meticulously formulated.

12.1.4 [ N (= quiz) + Prep. about ] : This pattern accommodates the noun 'quiz' and the preposition 'about', which is to be followed by the target topic. Such a collocation can be contextualised in a sentence like this one:

113. It was a quiz about the week's news. 


\section{Conclusions:}

Throughout this research-paper, the researcher has come up with a number of findings :

1. All words in English, let alone academic terms,can be better interpreted and properly explicated through context.

2. The context within which a word is used must be syntactically- based and semantically- well- knit.

3. Words in isolation cannot operate properly; that is to say, it is hard for us to tell the meaning as this meaning may, very possibly, be vague and unguessable until it has been contextualised.

4. Language, in view of this desperate need for contextualisation, is definitely regarded as context-sensitive or context-restricted.

5. In English, words work properly and naturally within their convenient environment, i.e. within certain collocations.

6. Such collocations undoubtedly contribute to the fluent natural use of language.

7. Both contextualisation and collocation render the use of language smooth, natural and optimal.

Recommendations : On the basis of this study, the researcher finds it of paramount importance to put forward the following recommendations :

1. Special attention should be paid to the context within which a word is used so as to save both time and effort in the learning process.

2. Learners of English are advised to learn a word together with its collocations so as to attain an overall mastery of how language works.

3. To gain a good command of English, the learner must contextualise a word alongside its collocations, or rather learn a word, not in isolation, but in its natural environment within a well-maintained context. 


\section{References:}

1. Adelson-Goldstein, Jayme of Norma Shapiro; (2008); Oxford Picture Dictionary; $2^{\text {nd }}$ edition: GB: Oxford University Press.

2. Ba'albaki, Munir; (1974); Al-Mawrid (English-Arabic); Beirut Dar-ElIlmLilmadayeen.

3. Barrett, Grant; (2008); Cambridge Dictionary of American English; $2^{\text {nd }}$ edition; England: Cambridge University Press.

4. Eckersley, C.E.\& Jean Eckersky; (1983); A Comprehensive English Grammar; London: Longman House.

5. McCarthy, Michael\& Felicity O Dell; (2008); English Collocations in use: London: Cambridge University Press.

6. Merriam-Webster Dictionary Online.

7. Murphy, Raymond; (2008); English Grammar in Use: GB. Oxford University Press.

8. Quirk, Randolph; (1983); A University Grammar of English; England: Longman House.

9. Shaw, John Robert\& Janet Shaw; (1983); Dictionary of the English Language; Tunisia: Bouslama.

10. Webster, Merriam; (1972); Webster's Intermediate Dictionary; U.S.A G\&C. Merriam Co.

11. Webster, Merriam; (1980); Webster's New World Dictionary; U.S.A G\&C. Merriam Co.

12. Wright, Jon; (1999); Idioms Organiser; O.K. Colour Press, London.

13. http://www.thefreedictionary.com/academic.

14. http://en.oxforddictionaries.com. 